\title{
JC Virus and Lung Adenocarcinoma: Fact or Myth?
}

\author{
EMANUELE SINAGRA ${ }^{1,2}$, DARIO RAIMONDO ${ }^{1}$, ELENA GALLO $^{3}$, MARIO STELLA $^{3}$, \\ MARIO COTTONE ${ }^{4}$, FRANCESCA ROSSI ${ }^{1}$, MARCO MESSINA ${ }^{5}$, MASSIMILIANO SPADA ${ }^{5}$, \\ GIOVANNI TOMASELLO ${ }^{2,6}$, GIUSEPPE FERRARA ${ }^{7}$ and AROLDO GABRIELE RIZZO ${ }^{3}$ \\ ${ }^{1}$ Gastroenterology and Endoscopy Unit, Fondazione Istituto San Raffaele - G. Giglio, Cefalu, Italy; \\ ${ }^{2}$ Euro-Mediterranean Institute of Science and Technology (IEMEST), Palermo, Italy; \\ ${ }^{3}$ Unit of Pathology, University of Palermo, Palermo, Italy; \\ ${ }^{4}$ DIBIMIS, Unit of Internal Medicine, University of Palermo, Palermo, Italy; \\ ${ }^{5}$ Oncology Unit, Fondazione Istituto San Raffaele-G. Giglio, Cefalu, Italy; \\ ${ }^{6}$ Section of Human Anatomy, BIONEC Department, University of Palermo, Palermo, Italy; \\ ${ }^{7}$ Strategic Direction, Fondazione Istituto San Raffaele-G. Giglio, Cefalu, Italy
}

\begin{abstract}
Background/Aim: An association has been reported between lung cancer and John Cunningham (JC) virus infection. The aim of this study was to evaluate the prevalence of JC virus in a small cohort of patients with lung adenocarcinoma and assess its presence in nodal metastasis. Materials and Methods: Consecutive samples of 13 surgically-removed lung tumors and 13 surrounding normal cancer-free tissues were selected. Five cases included metastatic lymph nodes. JC virus infection was assessed through nested PCR. Results: Seven out of thirteen patients with lung adenocarcinoma had a positive PCR test for JC virus. One of the five patients with nodal metastasis had a positive PCR test for JC virus. None of the thirteen specimens from the control group presented with JC virus infection. The difference between the two groups regarding $J C$ virus infection was statistically significant $(p=0.008)$. Conclusion: Our study suggests that JC virus might be involved in lung carcinogenesis.
\end{abstract}

Viral etiology of human tumors is an intriguing subject. Until now, several viral species have been detected in human cancers. John Cunningham virus (JCV) infects a large proportion of the population worldwide and $80 \%$ to $90 \%$ of adults are seropositive $(1,2)$. Primary infection occurs during childhood and remains asymptomatic, the virus persisting quiescent in the kidneys and lymphoid tissues. However, $\mathrm{JCV}$ may be activated when the immune system is impaired

Correspondence to: Emanuele Sinagra, Fondazione Istituto G. Giglio, Contrada Pietrapollastra Pisciotto, 90015 Cefalù, Italy. Tel: +393921920712, e-mail: emanuelesinagra83@googlemail.com

Key Words: JC virus, lung adenocarcinoma, T-antigen.
(3). There are two possible outcomes of infection of a cell by JCV. In permissive cells which are able to replicate viral DNA the result is a lytic infection, progressive multifocal leukoencephalopathy (PML) with viral amplification. Nonpermissive cells do not support viral DNA replication and the consequence is an abortive infection or cell malignant transformation (oncogenesis) (3).

JCV can transform cells in culture and has also been confirmed to be oncogenic in animal models (4). JCV DNA sequences have been detected in several kinds of human malignancies, including brain tumors of glial origin and medulloblastomas, epithelial tumors, such as colon, and prostate tumors, and esophageal carcinomas (5-10). However, non-cancerous samples of lungs of adult and pediatric PML cases, tonsillar stromal and upper and lower human gastrointestinal tract tissues may also be occasionally positive (11-13). A report indicates that in humans, the lung expresses abundant levels of JCV receptor-type sialic acids which mediate JCV infection (14).

The detection of JCV in tonsillar tissue might suggest that the upper respiratory tract may be the site of initial infection. In addition, JCV has been demonstrated in a pulmonary papillary adenocarcinoma, a pseudomesotheliomatous carcinoma, and one case of cystic brochioloectasis by hybridization using JCV probes (15).

The aim of this study was to evaluate the prevalence of JCV in a small cohort of patients with lung adenocarcinoma and assess its presence in nodal metastasis.

\section{Materials and Methods}

Consecutive samples of 13 surgically removed lung tumors, from immunocompetent patients with no signs or symptoms of progressive multifocal leukoencephalopathy, were selected from the Patient 
Table I. Clinical and pathological features of the patients with lung adenocarcinoma.

\begin{tabular}{lc}
\hline Age (mean) & 68.5 \\
Gender (Male:Female) & $9: 4$ \\
Grading & G1: $4 / 13$ \\
& G2: $7 / 13$ \\
& G3: $2 / 13$ \\
Staging according pTNM (n/total number) & $\mathrm{T} 1,4 / 13$ \\
& $\mathrm{~T} 2,6 / 13$ \\
& $\mathrm{~T} 3,3 / 13$ \\
$\mathrm{~T} 4,0 / 13$ \\
$\mathrm{~N} 0,8 / 13$ \\
Patients with positive PCR for JC virus in the neoplastic tissue (n, \%) & $\mathrm{N} 1,2 / 13$ \\
Patients with positive PCR for JC virus in the normal tissue without cancer (n, $\%)$ & $\mathrm{N} 2,3 / 13$ \\
Patients with nodal metastasis (n/total number, $\%)$ & $\mathrm{M} 0,13 / 13$ \\
Patients with nodal metastasis and nodal positivity of PCR for JC virus (n, $\%)$ & $7 / 13(53.8 \%)$ \\
\hline
\end{tabular}

Charts of Ospedali Riuniti "Villa Sofia- V. Cervello". The surrounding normal tissues without cancer were used as a control group. Five cases included lymph nodes sample, all sites of metastasis. All specimens were formalin-fixed and paraffin embedded. Nested PCR was performed in the tumor sample and in the surrounding normal tissue without cancer, to detect JCV infection.

The clinico-pathologic details of the lung cancer and normal cases are summarized in Table I.

DNA extraction. Paraffin-embedded tissues were sectioned at 10 micron and five sections were cut with a standard microtome and transferred into a $1.5 \mathrm{ml}$ microtube. To prevent cross-contamination between the samples, the microtome blade was washed with xylene and ethanol after sectioning of each block.

Genomic DNA was extracted from paraffin embedded tissue section using the ZR Genomic DNA-Tissue Miniprep (Zymo Research, California, USA), according to the manufacturer's recommendations.

Extreme caution was taken to perform all preparatory polymerase chain reaction (PCR) steps, including DNA extraction in a separate room isolated from any post-PCR samples to prevent contamination. All the DNA samples were amplified using beta-globin primers (fragment of 175bp) to confirm their integrity.

Nested PCR for the JCV genome. For the detection of JCV gene sequences, PCRamplifications were performed using gene-specific primers for T-antigen.

For JC virus T-antigen, T1 and T2 (nucleotides 3049-3069 of the Mad-1 strain, 5' TGGCCTGTAAAGTTCTAGGCA 3' and 32293207, 5' GCAGAGTCAAGGGATTTACCTTC 3' respectively) which amplify sequences in the $\mathrm{NH}_{2}$-terminal region of the $\mathrm{JC}$ virus T-antigen, were used for the first PCR, whereas T1 and T3 (nucleotides 3193-3171, 5' AGCAACCTTGATTGCTTAAGAGA 3') were used for the second PCR (110 bp) (16). The PCR reaction mixture contained $0.5 \mathrm{U}$ Taq polymerase, $1 \mathrm{x}$ PCR Buffer $(50$ $\mathrm{mmol} / \mathrm{L} \mathrm{KCl}$ and $10 \mathrm{nmol} / \mathrm{L} \mathrm{MgCl}_{2}, 10 \mathrm{pmol}$ of each dNTPs, 1.5 $\mathrm{mmol} / \mathrm{L} \mathrm{MgCl}_{2}$, 10 of each primer and 100-200 ng of extracted
DNA. PCR conditions were as follows: denaturation at $95^{\circ} \mathrm{C}$ for 10 min, followed by 30 cycles of denaturation at $95^{\circ} \mathrm{C}$ for $15 \mathrm{~s}$, annealing at $55^{\circ} \mathrm{C}$ for $30 \mathrm{~s}$ and extension at $72^{\circ} \mathrm{C}$ for $30 \mathrm{~s}$ followed by 7 min final extension at $72^{\circ} \mathrm{C}$. Nested PCR was carried out as the first PCR cycles, using 1\% (volume) of the first PCR product and with the use of internal primers. The PCR amplification products were run on $2 \%$ agarose gel, stained with ethidium bromide and visualized under ultraviolet light.

Statistical analysis. The difference in the prevalence of JCV in the lung samples between the two groups of patients (with lung adenocarcinoma and control group) was assessed through the chisquare test. For all analyses, $p<0.05$ was considered to indicate statistical significance.

\section{Results}

The clinical and demographical data of the study population are summarized in Table I.

Seven out of 13 patients $(53.8 \%)$ with lung cancer (all with adenocarcinoma) had a positive PCR test for JCV. One of the five patients (20\%) with nodal metastasis had a positive PCR test for JCV at this site. None of the thirteen specimens $(0 \%)$ from the control group presented JCV infection. The difference between the two groups of patients (with lung adenocarcinoma and control group) regarding JCV infection was statistically significant (Chi square 9.58, Yates correction $=7.04, p=0.008)$.

\section{Discussion}

JCV DNA sequences and proteins have been detected in a broad range of human tumors of glial and non-glial origin, including gliomas, ependymomas and medulloblastomas, as 
well as in several non-neural clinical specimens of upper and lower gastrointestinal tumors $(17,18)$. These data suggest that JCV can infect a wide range of cell types, but its role in human carcinogenesis is still unclear.

Lung cancer is the leading cause of cancer-related mortality in western countries (19). Cigarette smoking, environmental pollution and asbestos are considered the main risk factors. However, they cannot explain all lung cancer cases. Interest in the role of viral infections in human cancerss has increased in the last few years. Until now few studies have been conducted to show the incidence of JCV infection in lung cancer.

In the study performed by Giuliani and coworkers (1), who analyzed the incidence of Bovin Kidney Virus, JCV, Simian Virus 40 and Human Cytomegalovirus sequences in 78 lung tumurs and their surrounding normal tissue, JCV sequences were both amplified in one tumor only. This was the first report describing the presence of JCV -DNA in lung tumors.

In a study by Zheng et al. (20), JCV was examined by targeting its T-antigen in lung carcinomas $(n=103)$ and normal lung tissues $(n=18)$; additionally, expression of Ki67 , caspase- $3, \beta$-catenin, $\mathrm{p} 53$, and $\mathrm{Rb}$ was analysed. In this study normal lung tissue was positive significantly less frequently, and contained a lower number of JCV copies than lung carcinomas $(p<0.05)$, and the number of copies was lower in lung adenocarcinomas than in squamous, small or large cell carcinomas $(p<0.05)$. The number of JCV copies correlated closely with sex, expression of Ki-67 and membrane $\beta$-catenin $(p<0.05)$. These data confirmed, as suggested by Giuliani et al. (1), that JCV may be involved in lung carcinogenesis. Furthermore, as mentioned above, previous reports indicated that terminal alpha 2, 6-linked sialic acid is a critical component of the JCV receptor, which is abundantly expressed in normal lung (12). These data suggested that JCV might be closely linked to the malignant transformation of pulmonary epithelial cells and supported the notion that the respiratory tract might be a portal of entry for JCV infection (13).

Finally, Abdel Aziz and coworkers (20) investigated the presence of JCV DNA in 62 lung tumors, along with 23 samples of normal lung tissue, targeting the T-antigen, viral protein, and agnoprotein. The JCV DNA was present in 33 of the lung cancers and 10 of the normal samples. Interestingly, T-antigen was found in cancer cells in metastatic lymph nodes in 3 out of 4 cases $(p=0.042)$ and was more frequently detected in adenocarcinomas than in squamous cell carcinomas $(p=0.038)$. Immunohistochemistry showed significant correlations between T-antigen and p53 $(p=0.022)$ and also nuclear detection of b-catenin $(p=0.021)$. The authors concluded that the T-antigen may play a role in oncogenesis of lung cancers through inactivation of p53 and dysregulation of the Wnt signaling pathways (21).
The main limitation of the present study is represented by the small amount of data, due to the small number of patients included, supporting the possible involvement of JCV in nodal spreading in patients with lung adenocarcinoma.

Forthcoming prospective case-control studies, with a larger number of patients and targeted to evaluate migration and invasion, (with techniques aiming at demonstrating the presence of JCV within the neoplastic cells and viralassociated abnormalities (i.e. genetic damage) could clarify the true prevalence of JC virus in lung cancer, paying particular attention to the role of T-antigen in oncogenesis.

\section{Conflicts of Interest}

None declared for all the authors.

\section{References}

1 Giuliani L, Jaxmar T, Casadio C, Gariglia M, Manna A, D'Antonio D, Syrjanen K, Favalli C and Ciotti M: Detection of oncogenic viruses (SV40, BKV, JCV, HCMV, HPV) and p53 codon 72 polymorphism in lung carcinoma. Lung Cancer 57: 273-281, 2007.

2 Bouvard V, Baan R, Straif K, Grosse Y, Secretan B, El Ghissassi F, Benbrahim-Tallaa L, Guha N, Freeman C, Galichet L, Cogliano V and WHO International Agency for Research on Cancer Monograph Working Group: A review of human carcinogens--Part B: biological agents. Lancet Oncol 10: 321$322,2009$.

3 White MK and Khalili K: Polyomaviruses and human cancer: molecular mechanisms underlying patterns of tumorigenesis. Virology 324: 1-16, 2004.

4 Del Valle L, Gordon J, Ferrante P and KhaliliK: JC virus in experimental and clinical brain tumorigenesis. In: Human Polyomaviruses: Molecular and Clinical Perspectives. Khalili K, Stoner GL (eds.). New York: Wiley-Liss pp. 409-430, 2001.

5 Del Valle L, Gordon J, Assimakopoulou M, Miklossy J, Khalili $\mathrm{K}$ and Gordon J: Detection of JC virus DNA sequences and expression of the viral regulatory protein T-antigen in tumors of the central nervous system. Cancer Res 61: 4287-4293, 2001.

6 Del Valle L, Gordon J, Enam S, Delbue S, Croul S, Abraham S, Radhakrishnan S, Assimakopoulou M, Katsetos CD and Khalili $\mathrm{K}$ : Expression of human neurotropic polyomavirus JCV late gene product agnoprotein in human medulloblastoma. J Natl Cancer Inst 94: 267-273, 2009.

7 Enam S, Del Valle L, Lara C, Gan DD, Ortiz-Hidalgo C, Palazzo JP and Khalili K: Association of human polyomavirus JCV with colon cancer: evidence for interaction of viral T-antigen and beta-catenin. Cancer Res 62: 7093-7101, 2002.

8 Zambrano A, Kalantari M, Simoneau A, Jensen JL and Villarreal LP: Detection of human polyomaviruses and papillomaviruses in prostatic tissue reveals the prostate as a habitat for multiple viral infections. Prostate 53: 263-276, 2002.

9 Del Valle L, White MK, Enam S, Oviedo SP, Bromer MQ, Thomas RM , Parkman HP and Khalili K: Detection of JC virus DNA sequences and expression of viral $\mathrm{T}$ antigen and agnoprotein in esophageal carcinoma. Cancer 103: 516-527, 2005. 
10 Delbue S, Pagani E, Guerini FR, Agliardi C, Mancuso R, Borghi E, Rossi F, Boldorini R, Veggiani C, Car PG and Ferrante P: Distribution, characterization and significance of polyomavirus genomic sequences in tumors of the brain and its covering. $J$ Med Virol 77: 447-454, 2005.

11 Newman JT and Frisque RJ: Identification of JC virus variants in multiple tissues of pediatric and adult PML patients. J Med Virol 58: 5879-5886, 1999.

12 Monaco MC, Jensen PN, Hou J, Durham LC and Major EO: Detection of JC virus DNA in human tonsil tissue: evidence for site of initial viral infection. J Virol 72: 9918-9923, 1998.

13 Ricciardiello L, Laghi L, Ramamirtham P, Chang CL, Chang DK, Randolph AE and Boland CR: JC virus DNA sequences are frequently present in the human upper and lower gastrointestinal tract. Gastroenterology 119: 1228-1235, 2000.

14 Eash S, Tavares R, Stopa EG, Stopa EG, Robbins SH, Brossay L and Atwood WJ: Differential distribution of the JC virus receptor-type sialic acid in normal human tissues. Am J Pathol 164: 419-428, 2004.

15 Galateau-Salle F, Bidet P, Iwatsubo Y, Gennetay E, Renier A, Letourneux M, Pairon JC, Moritz S, Brochard P, Jaurand MC and Freymuth F: SV40-like DNA sequences in pleural mesothelioma, bronchopulmonary carcinoma, and non-malignant pulmonary diseases. J Pathol 184: 252-257, 1998

16 Zheng, Murai Y, Hong M, Nakanishi Y, Nomoto K, Masuda S, Tsuneyama $\mathrm{K}$ and Takano Y: JC virus detection in human tissue specimens. J Clin Pathol 60: 787-793, 2007.
17 Burnett-Hartman AN, Newcomb PA and Potter JD: Infectious agents and colorectal cancer: a review of Helicobacter pylori, Streptococcus bovis, JC virus, and human papillomavirus. Cancer Epidemiol Biomarkers Prev 17: 2970-2979, 2008.

18 Sinagra E, Raimondo D, Gallo E, Stella M, Cottone M, Orlando A, Messina M, Tomasello G, Lo Monte AI, La Rocca E and Rizzo AG: Could JC virus provoke metastasis in colon cancer? World J Gastroenterol 20(42): 15745-15749, 2014.

19 Ferlay J, Bray F, Pisani P and Parkin DM: GLOBOCAN 2000: cancer incidence, mortality and prevalence worldwide, version 1. 0. IARC cancer base. Lyon: IARC Press; 2001.

20 Zheng H, Abdel Aziz HO, Nakanishi Y, Masuda M, Saito H, Tsuneyama K and Takano Y: Oncogenic role of JC virus in lung cancer. J Pathol 212: 306-315, 2001.

21 Abdel Aziz HO, Murai Y, Hong M, Kutsuna T, Takahashi H, Nomoto K, Murata S, Tsuneyama k and Takano Y: Detection of the JC virus genome in Lung cancers: possibile role of the Tantigen in lung oncogenesis. Appl Immunohistochem Mol Morphol 15: 394-400, 2007. 